\title{
FARMERS' ACCESS TO INTERNET INFORMATION: PATHWAYS, INTERESTS AND COST
}

\author{
A Typical Survey in Southern Hebei Province of China
}

\author{
Gubo Qi ${ }^{1}$, Haimin Wang ${ }^{1}$, Ting Zuo, ${ }^{1, *}$ \\ ${ }^{1}$ College of Humanitites and Development, China Agricultural University, Beijing, China, \\ 100094 \\ * Corresponding author, Address: College of Humanities and Development, China \\ Agricultural University, 2 Yuanmingyuan West Road, Beijing, 100094, P. R. China, \\ Tel:+86-10-62731319, Fax: +86-10-62731027,Email: zuoting@cau.edu.cn
}

Abstract: $\quad$ Set in six rural communities in southern Hebei Province of China, the present study focuses on rural farmers' access to, interests about and management of internet information. With the perspective of farmers, this empirical study attempts to understand the potential effects of information technology on agricultural information system and to capture its development prospect as well. The research findings indicate that 1 ) how the surveyed rural residents gain access to internet information and to what extent the internet as media is acceptable to farmers are dependent on such factors as individual education background, age, family income, as well as outside interventions; 2) innovative information technology plays a significant role in improving local livelihoods and accelerating local development; 3) poverty reduction through information technology has laid positive but limited impact towards rural residents' understanding, learning and utilization of the internet.

Keywords: farmers' access, innovative information technology, poverty reduction

\section{BASIC DATA OF THE SURVEYED INDIVIDUALS AND HOUSEHOLDS}

Along with more and more open and consistent market and some agencies and companies' promotion on information technology in rural area, there are also a certain number of townships, villages and rural residents that have

Qi, G., Wang, H. and Zuo, T., 2008, in IFIP International Federation for Information Processing, Volume 259; Computer and Computing Technologies in Agriculture, Vol. 2; Daoliang Li; (Boston: Springer), pp. 1155-1168. 
already been successfully accessing through telephone lines to internet to search for marketing information and even to release the product information (Li, 2003). Out of those cases, UNDP has initiated the "Project on Poverty Reduction through Information Technology in Rural China" in 12 villages of 5 counties since 2000. The project has so far witnessed preliminary achievements as expected (Wang, 2003). This empirical research attempts to understand the potential effects of information technology on agricultural information system and to capture its development prospect as well, with focusing on farmers' perspectives.

The typical survey was conducted in six villages in Wuan County of Hebei Province, including Menwangzhuang village, Shangdian village, Qianboshan village and Qianqu village of Huoshui Township, and Pushang village and Xiazhuang village of Paihuai township. Among them, Menwangzhuang village, Shangdian village and Pushang village belong to project villages whereas their neighboring villages: Qianqu village, Qianboshan village and Xiazhuang village are all non-project villages. The entire survey sample contains 189 households (individuals). 95 respondents, inclusive of 37 man and 58 women are from project villages, taking up $50.3 \%$ of the total. The rest 94 respondents being consisted of 55 men and 39 women are from non-project households, holding up about 49.7\%. In general, the sample consists of 92 male participants (48.7\%) and 97 female ones $(51.3 \%)$.

Considering annual income of surveyed household with average 4 family members- RMB 8728.1 Yuan, the surveyed villages are relatively with higher living standard than the average standard in rural China. Off-farm work, wages and small business are three main income sources contributing to $78 \%$ of total income. There is only $20.3 \%$ of total income coming from agricultural production.

Figure 1 shows the structure of households' expenditure. Expenses of housing, education, medicine and the medical service, and food make up $72.99 \%$ of the total expenditure. As to the facilities, TV set and telephone are popularly used by $97.9 \%$ and $67 \%$ households respectively, while few households can afford to the computer. Some even hold the view that computer is useless in rural areas. When it comes to entertainment, $71.4 \%$ of the respondents reported "watching TV", 12.4\% responded "visiting relatives" and $8.6 \%$ chose "playing cards/mahjong". The most frequently chosen TV channels includes CCTV-1, CCTC-7, Hebei Provincial 


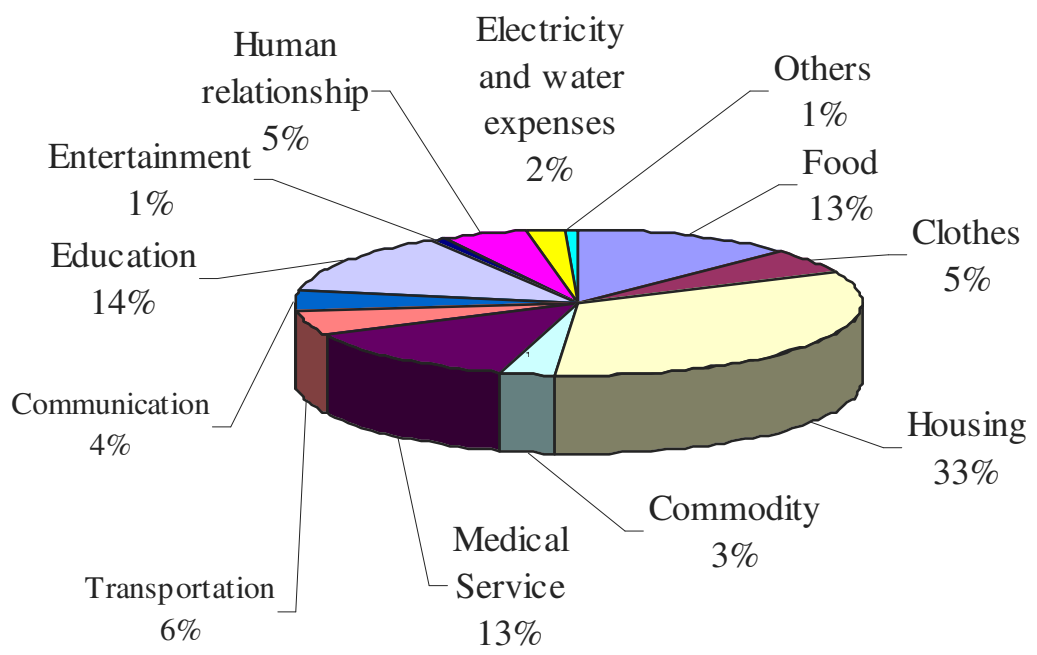

Figure 1. Expenditure structure of the households

Television, Henan Provincial Television, etc. and the most frequently watched programmers are reported as Weather Forecast, Focus Interview, News, TV Series, Agricultural Extension programmers and so on. Some households who have showed strong interest in innovative agriculture technology watch frequently the CCTV-7 for new technology and have managed to apply in reality to yield fair results.

To better understand local situations and local people needs, this survey explored the main problems faced by the farmers and their expected assistance. Insufficient access to information, insufficient technology, insufficient training opportunities and difficulties of getting loan took largest proportions, as being showed in Figure 2. As to assistance, 97 persons $(51.9 \%)$ of the surveyed demand "more financial support", 49 respondents (26.2\%) request "better production technology/breeds", and 26 respondents (13.9\%) mentioned "more market information". It can be concluded that rural residents have strong demands for market information, apart from financial support and technical assistance. If new information and technology generated from internet network can be applied in agricultural production, it will be surely of great significance and benefit to local farmers. 


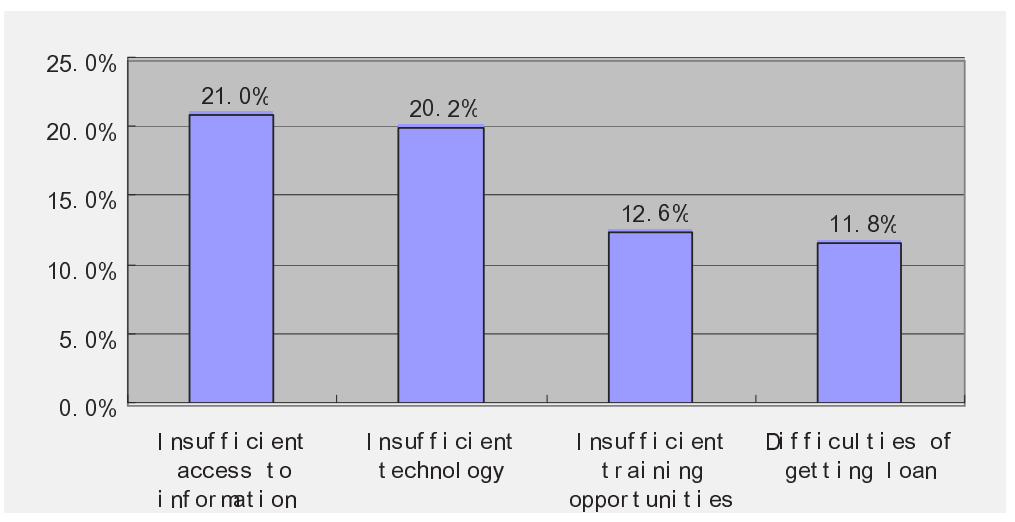

Figure 2. Main problems faced by the farmers

\section{FUNDAMENTS OF FARMERS' INFO SYSTEM}

\subsection{Information Farmers Interested in}

A total of 188 valid samples were gathered for this analysis, out of which 94 samples are for the project villages and 94 for non-project villages. The questionnaire contains 13 categories of information. It is found out that $45.7 \%$ of the investigated are interested in information of new technology wherein there is no significant difference between that of project villages (48.8\%) and that of non-project villages $(51.2 \%)$, and that $12.8 \%$ of the investigated are interested in where to get jobs wherein the percentage of project and non-project villages are fifty-fifty. Immediately after the topranking two categories is information on market price of quotidian livelihood goods, day-to-day knowledge about medical care, health and education, and basic knowledge on laws. The summing-up of the three categories show that $60.9 \%$ of the investigated are interested on new technology, 33.3\% interested on market demands for products, $33.2 \%$ interested on day-to-day knowledge (of which $17.8 \%$ of the total investigated chose this kind of knowledge as the third most interesting). Taking new technology as the top priority suggest a fairly strong desire of farmers for technological information, and the fact that as many as $12.8 \%$ of those searched for needed information on employment opportunities is a demonstration of the outward migration trend of the surplus labors from the rural areas. 


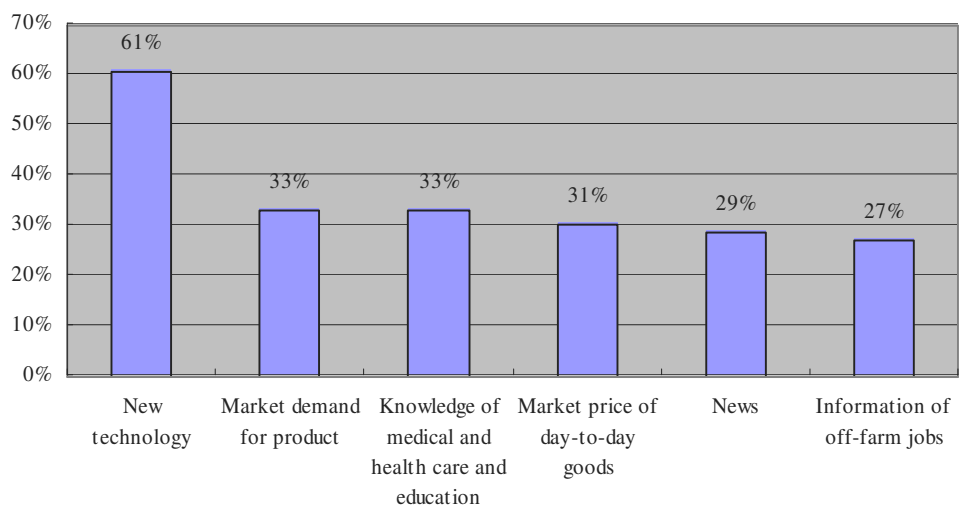

Figure 3. Information that the farmers are interested in

\subsection{Sources and Channels of Acquiring Information}

Relatives, friends and TV broadcasting constitute the primary sources for people to receive information, while books, newspapers and magazines play certain role in serving that purpose as well. In terms of other sources of obtaining information, the effect of Villagers Committees and their loudspeakers is deemed much poorer than expected, only as little as 3.2\% of the respondents consider official institutions in charge of disseminating technology at the township level as useful, and merely $5.9 \%$ replied favorably for the township governments. The internet usage is poor: only $1.6 \%$ of the surveyed have ever searched for information on their own, only $2.7 \%$ have ever got help from the materials disseminated by the information centers, $6.4 \%$ of them have ever searched for information with the help of the people working at the information centers. That is to say, farmers seldom used internet and their ability to use it is inadequate. All the three who replied that they ever "searched the internet independently" and all the 12 who said "yes" to "ever searched for information with the help of the people working at the information centers" are from the project villages. In addition, four out of those five who were affirmative that they used "materials printed out by information centers" are from the project villages. Presumably most of the investigated had access to internet through the info centers established under the project of internet poverty alleviation projects. As $100 \%$ of those who ever "searched the internet independently" or "searched for information with the help of the people working at the information centers" are from the project villages, and as many as $80 \%$ of those used "materials printed out by information centers" are from the project villages, there is no doubt that establishing information centers plays a positive role in promoting information awareness. 


\subsection{Attitude and Judgment Regarding New Information}

Table 1 show that most farmers, accounting for $86 \%$ of total respondents, are interested in new technology or new information. And there is not significant difference between project villagers and non-project villagers. We can find the main reason of poor economic conditions or inadequate education preventing the application of those innovates in table 2 .

Table 1. The interests of the farmers on new technology or information

\begin{tabular}{llll}
\hline Village & $\begin{array}{l}\text { Number and \% of farmers } \\
\text { without interests }\end{array}$ & $\begin{array}{l}\text { Number and \% of } \\
\text { farmers with interests }\end{array}$ & $\begin{array}{l}\text { Total number and \% } \\
\text { of respondents }\end{array}$ \\
\hline Project & $81(88.0 \%)$ & $11(12.0 \%)$ & $92(49.7 \%)$ \\
Non-project & $79(85.0 \%)$ & $14(15.0 \%)$ & $93(50.3 \%)$ \\
Total & $160(86.0 \%)$ & $25(14.0 \%)$ & $185(100 \%)$ \\
\hline
\end{tabular}

Table 2. Reasons on their no interests on new technology or information

\begin{tabular}{llllll}
\hline Village & $\begin{array}{l}\text { The number } \\
\text { and \% of } \\
\text { answers of } \\
\text { 'could not } \\
\text { apply due to } \\
\text { fund limitation' }\end{array}$ & $\begin{array}{l}\text { The number and } \\
\text { \%of answers of } \\
\text { due to low } \\
\text { education level' }\end{array}$ & $\begin{array}{l}\text { The number } \\
\text { and \% of } \\
\text { answers of } \\
\text { 'Fear of } \\
\text { failure' }\end{array}$ & $\begin{array}{l}\text { The number } \\
\text { and } \% \text { of } \\
\text { answers of } \\
\text { 'other } \\
\text { reasons' }\end{array}$ & $\begin{array}{l}\text { Total } \\
\text { number and } \\
\text { respondents } \\
\text { respons }\end{array}$ \\
\hline $\begin{array}{l}\text { Project } \\
\text { Non-project }\end{array}$ & $3(27.3 \%)$ & $6(54.6 \%)$ & $0(0 \%)$ & $2(18.1 \%)$ & $11(45.8 \%)$ \\
Total & $6(25 \%)$ & $3(23.1 \%)$ & $1(7.6 \%)$ & $6(46.2 \%)$ & $13(54.2 \%)$ \\
\hline
\end{tabular}

As to the sources of those information that the respondents care most, relatives and neighbors was ranked as the first one out of 16 information sources listed by the farmers, and the following ranks are as following: TV program, newspapers and magazines, books, village broadcasting, village committee, telephone call, radio, relatives doing off-farm work outside, children studying outside, information center staff's help, township government, township technology institutes, materials distributed by the information center, law consultation departments, and internet browser, etc. Although through internet browser was ranked as the last one, both project village and non-project village have farmers who started adopting this kind of source. And in project village, there were $6 \%$ respondents using internet browser independently, which is 4.4 points higher than that of non-project village. Relatives and TV programs are still the ones they trusted most and they think most useful. 


\section{BRIEFING ON FARMERS' USE OF INTERNET INFORMATION TECHNOLOGY}

\subsection{Use of Internet by Farmers}

Internet can now be witnessed in very corner of the cities all around the country and it has substantially improved the efficiency of all urban sectors. However, to what extent has the internet influenced the rural area? 76 participating households $(41.1 \%)$ report that one of the family members is capable of using internet, whereas some reflect that more than one family member can make it. It seems that quite a lot of rural residents in survey area are able to use computer, which has laid a solid foundation for information network construction in rural areas.

The proportion of households capable of using computer in project village is much higher than that in non-project villages. Specifically, 49 households $(51.6 \%)$ of the households in project villages are able to operate computers. In non-project villages, 27 responding households (30\%) were using computers, mainly influenced by the project villages. It can hence beconcluded that poverty reduction through information technology has obtained obtained its preliminary effects on advancing the rural information network.

Out of 113 respondents, $68.4 \%$ learned basic computer use skills at school, $22.4 \%$ acquired from the information center, and 5.3\% from the computer training courses. These are the three major approaches for the local people to learn the computer. Ever since the implementation of the information poverty alleviation, the Science and Technology Bureau in Wu'an County has organized quite a few computer internet training workshops, each of which were attended by quite a large number of local residents. From all these results, it may be concluded that information center has played a preliminary but positive role in helping local farmers learn and use internet.

Who are the computer users and what characteristics do they have? The research reveals that among all of the computer users, "my son can" and "my daughter can" have occupied $29.3 \%$ and $26.7 \%$ of the total. "Both son and daughter can" accounts for $34.7 \%$. It is observed that most of the computer users are youths, with higher education background. Some of them are even registered students, who have learned to use computers in school. Besides that, the proportion of the male computer users is higher than their female counterparts. Also, most attendees of the computer training workshops are man whereas women usually merely took a curious look and left.

To verify the correlation between household income and the use of computers, the result shows that the higher the family income is, the more 
possibility in using computers. For instance, no one earning below RMB 1000 per year is reported to be able to use the computer. At the income ranges of RMB "1000-3000", "3000-6000", "6000-10000", "10000-20000" and above 20000, the ratio of computer use amount up from $19.0 \%, 35.6 \%$, $48.0 \%, 63.2 \%$ and to $84.6 \%$ respectively. Along with the increase of the income, the proportion of the family who can use the computer is gradually going up, which demonstrates the obvious correlation between family income and computer use.

\subsection{Farmers' Cognition Towards Internet Information}

182 valid samples altogether have responded to this aspect, inclusive of $94(51.6 \%)$ from project village and 88 (48.4\%) from the non-project village. Within project village, $72(76.6 \%)$ of the survey reported that they know information can be searched from internet whereas 22 (23.4\%) interviewees provided negative answer. Contrast in non-project villages, there were 46 (52.3\%) participants knowing and $42(47.7 \%)$ unknowing about the fact that internet is source of information. Such an observable difference between non-project households and project households has to certain extent reflected the progress brought alongside with the poverty reduction project.

When answering the question "How do you know that internet is one of the sources of information?" $32(44.4 \%)$ out of the 72 respondents from project village referred to the information center, $14(19.4 \%)$ referred to the TV, and $13(18.1 \%)$ for other ways. In the non-project village, $30(65.2 \%)$ of the 46 surveyed referred to the TV, 9 (19.6\%) referred to their children who were perusing their study outside the village, and $6(13 \%)$ for other ways, like knowing it from neighbors, friends, broadcast and so on. All of these have shown that the information center built by the project has contributed a lot for farmers to get new information from outside.

In addition, we have carried out a correlation analysis over "household income" and the "cognition about the internet information" and no significant correlation has been traced. The ratio between the known person and the unknown person in each income segment is nearly 1:2. Similarly, no significant correlation has been identified between gender and the cognition of internet information in that out the 182 respondent to this question, 58 women (31.9\%) and $60(33 \%)$ gave the positive answer. However, when it comes to education background, it is observed that the cognition rate increases along with the improvement of education level. 


\subsection{Use of Internet by Surveyed Households}

We have chosen 30 households respectively from the project village and the non-project village to compare who have earlier access to internet information. None of the 30 respondents randomly selected from non-project village had ever used internet whereas 10 out of the 30 households from project village had ever used internet, with 8 of them started as early as 2002 and 2 in 2003. The project has urged the villagers to accept such a new object as internet and it is deemed to have brought about changes to the village. It yet needs to be alert that there is still a long way to go before the rest $2 / 3$ of the villagers started to accept and use this new object.

81 individuals responded to the question that whether they know the relative knowledge before accessing to internet. 56 answered no and 25 answered yes. $8(32 \%)$ claimed to get the information through project training and $6(24 \%)$ learned from the book, $6(44 \%)$ reported other ways. To get a further understanding of the specific situation, we have done the comparison analysis regarding whether they know that they can get the information from the internet and whether they know the relative knowledge before accessing the internet. 68 out of the 118 households who believe that internet is an information source have participated this session, with 26 households claiming to know the relative knowledge before accessing and 42 do not. Among the other 64 households who don't know that internet is an information source, only one out of the 13 respondents claims to know the relative knowledge before accessing while the other 12 do not. Therefore, we can infer there is a great positive correlation between whether they can get information from internet and whether they know the relative knowledge. It is necessary to make the farmer household know that they can get the information they want from the internet before publicizing the internet knowledge in the rural area. Only in this way, it can inspire the farmer households' enthusiasm to learn the internet. Whereas, we should see that in the 68 households who know that they can get the information from the internet, there are only 26 households who know the internet knowledge, which has occupied $38.2 \%$ of the whole number. The other $61.8 \%$ still don't know about the internet knowledge. So if we want to get ground the internet knowledge widely, there is a long way to go before all farmer households know that they can get the knowledge from the internet. 


\section{ROLES OF THE INFORMATION CENTER}

\subsection{Approaches to Access Internet Information and Various Information Gained}

Responding to the "approaches to access internet information" are 52 households, with 18 (34.6\%) reported that they search for internet information by themselves while $26(50 \%)$ turned to others (mainly the information messenger at the info center) for help and the last one (1.9\%) gained related knowledge from the printouts at the info center. Though the village information center is currently the main place for villagers to log on the internet but the most favored venue is at home. $17(53.1 \%)$ of he 32 respondent prefers to access internet at home, 7 households (21.9\%) prefers independent search of information at information center and 6 households (18.8\%) likes dependent search of information at information center.

There are 48 persons who have answered the question of "what types of information have you gained from the internet". The first three options include the new technology, common sense knowledge in every day life, the price of the production materials, and the last three options are the product purchase venue, the living standard of the outsiders, the daily goods' price information. In terms of the use of information center, no particular trend has been identified. The frequency of info center visit range from once to 200 times, according to the 45 respondents. The duration in info center also depends, although most of them report that each visit cost less than two hours. When comparing the distance to info center with the frequency of info center visit, we find that 33 out of the 36 respondents, that is $91.7 \%$ of them, dwell a five-minute-walk distance away from info center,

From gender perspective, no obvious distinction has been diagnosed between gender and frequency of info center visit. Nor is there great correlation between education background and frequency in visiting info center. However, a close examination reveals that those 44 individuals who frequently visit the information center consist of 13 (29.5\%) people with primary schooling, $18(40.9 \%)$ with junior high education background, 6 (13.6\%) with above senior high education and two illiterate (4.5\%). It can be explained that the visitors to info centers are mostly students from primary and high schools, who have more curiosity and time to access internet.

\subsection{Internet Information and its Usage}

Among the 35 responding households, $17.8 \%$ use internet mainly for sending E-mail, $35.9 \%$ for playing games, chatting and watching the film, 
$15.4 \%$ for reading the news and the other $30.8 \%$ for other purposes including typing exercises and listening to music. From the analysis above, we can see that there are some wrong understandings on using the internet. Most of farmers have taken the internet as a kind of tool for pastime. Action needs to be taken to update their understanding and change their behavior so that internet can play a more positive role for their economic activities and income generation.

46 out of the 48 respondents regard it helpful to access internet information, while the rest two remain pessimistic on this. The 46 positive respondents prioritized the top two functions of internet to include "broadening the mind" ( 24 people, i.e. 50\%) and "providing of useful market information" ( 8 people, i.e.16.7\%)

When it comes to the impact of internet on daily life, $26(57.8 \%)$ out of the 44 respondents reported that internet had increased their contact with outside world, $10(22.2 \%)$ reflected that internet had helped them in improving income, $5(11.1 \%)$ have reported other impacts. Despite such a small sample, it can be inferred that farmers have noticed internet can bring about more information. Yet more efforts need to be done to strengthen the impact of internet in rural areas in an all-round way.

In terms of the difficulties in using internet to get information, 43 responding households prioritize the top three challenges to include awkward operation (15 people), insufficient computers (10), and not knowing how to locate needed information (5). It can be inferred that local farmers' poor knowledge about internet has added to the difficulty for them to access internet. When exposed to such a new invention as internet, it is very hard for farmers to effectively respond.

When asked the question whether there is some data that can not be found in the internet", $43(84.3 \%)$ out of the 51 interviewees in total reflected that internet is a better information source, $5(9.8 \%)$ believed that internet is no different from other information sources, and the rest $3(5.9 \%)$ households commented that internet can not compete with other means of information channels. It is also learned that these who are in favor of internet think that internet information is more swift and comprehensive, whereas these who are against internet actually had no experience in accessing internet information.

When responding to needed assistance in information access, 46 respondents prioritized their needs to include more training ( 27 households), more advice from professionals (9 households) and better access to internet (4 households). It can then be inferred that lack of internet related knowledge and shortage of internet professionals in rural areas have constitute the two major constraints for local farmers to access internet. 


\subsection{Cost of Internet Access and its Management}

93 households answered the question "what kinds of equipments are needed for accessing internet? 65 persons (69.9\%)'s gave negative answers while $28(30.1 \%)$ expressed that they know some of them. Among these 28 persons, 21 believed that a computer is necessary for accessing internet, 20 persons know that a phone line is needed, and 8 persons know that the modem should be used. However, $32(61.5 \%)$ of all 52 respondents did not even know how much money is needed for buying these equipments. For the rest 20 people who claimed to know exactly how much money is needed, they have provided diversified answers regarding to the actual prices of these equipment.

A closer examination indicates that 64 out of the above mentioned 93 respondents come from the project village, occupying $68.8 \%$ of the whole. Within the project household sample are 25 positive respondents (26.9\%) and 39 negative respondents $(41.9 \%)$. In contrast, the 29 respondents from the non-project village have provided 3 positive answer $(3.2 \%)$ and 26 negative one $(26 \%)$. It can be observed from these figures that there exists great disparity between project villages and non-project villages in this regard, in that households form project village have more exposure to computers and internet.

The same is true when drawing comparison between project villages and non project villages in terms of the cognition towards the needed equipment for internet connection. Among the 52 respondents, 45 households are in the project village, including 19 (36.5\%) answering yes, 26 (50\%) answering no. For the rest 7 from non-project village, only one surveyed claim to know while the other 6 remain ignorant in the regard.

When asked the question "would you like to pay for the internet service in the future once the provision of free service is terminated?" 90 farmer households have given the answer, among whom, 37 (41.4\%) persons are reluctant to pay and $53(58.9 \%)$ persons respond positively. When it comes how much one would like to pay, $42(87.5 \%)$ out of 48 respondent regarded it reasonable to pay for less than $3 \mathrm{RMB}$ per hour and 19 (39.6\%) prefer 1 RMB per hour, 12 (25\%) would like to pay 2 RMB per hour, 11 (22.9\%) choose 3 RMB per hour.

It, however, shall be point out that the 29 households are from non-project villages where there are no free internet service. So their willingness to pay deserves a second thought. Out of the 61 households from project village, 40 expressed their willingness to pay while 21 insisted on free service. Further interview indicates that $81.25 \%$ of these who are willing to pay actually would like to pay less than 3 yuan per hour for the service. According to our analysis, there is no significant correlation between household income and 
the willingness to pay, nor is there significant correlation between the frequency of visiting information center and the willingness to pay.

46 out of the 81 responding households, that is $56 \%$ of the total, had got plans to buy computer, whereas the rest 35 households (43.2\%). For these who have planed to buy computers, it is learned that $23(65.7 \%)$ households will take action once they have earned enough money, 7 (20\%) households would not buy it until their child has grown up, and the rest 5 households have provided other plans. In this case, no significant correlation has been identified between household income and the wiliness in buying the computer.

When drawing a comparison between project village and non-project village, we find that those residents from project village have much higher will in buying computer. Specifically, 20 out of the 39 respondents from the project village were going to buy computers, accounting for $51.3 \%$, leaving 19 respondents $(48.7 \%)$ with no specific plan to buy computers. In nonproject village, 15 out of the 42 respondents were going to buy computers, accounting for only $35.7 \%$, leaving 27 respondents (64.3\%) with no specific plan to buy computers.

\section{CONCLUSION}

As with the technical and economic development in rural areas, internet has become one of the available sources of information. The case in Hebei province has provided with very good implications. Through internet, farmers are capable of getting information about policy, market, technology and so on, to well support their own livelihood development. In the process of accessing internet information, there is high potential in encountering information filtering and false information. In this case, Info centers and information programmers shall be in place to provide due assistance. Meanwhile, it needs to be noticed that internet resources as a public good requires huge financial input. Otherwise, most farmers themselves would be unable to afford the internet services. It is hence suggested that internet development shall be enlisted as one of the most important public goods for the nation's New Countryside Construction Program.

\section{ACKNOWLEDGEMENTS}

The present study, especially the field work has been supported by the projects of UNDP and MOST while the Science and Technological Bureau 
of Wu' an County has also contributed to the organization of the field survey. The authors take full responsibility in explaining the views in this article.

\section{REFERENCES}

Li, Xiaoyun, Zuo, Ting. 2002 status of rural China. China Agricultural University Press. 2003, Beijing: 23-24

Rural department of State Development Research Center. Rural Public Service System in China. China Development Press. 2003

Wang, Haimin. Analysis of the mechanism of poverty reduction through internet and its impacts, 2003, Beijing: 5-6 